\title{
A new Western Pacific Tonguefish (Pleuronectiformes: Cynoglossidae): The first Pleuronectiform discovered at active Hydrothermal Vents
}

\author{
THOMAS A. MUNROE ${ }^{1,3} \&$ JUN HASHIMOTO ${ }^{2}$ \\ ${ }^{1}$ National Systematics Laboratory, National Marine Fisheries Service, NOAA, Smithsonian Institution, P.O. Box 37012, National \\ Museum of Natural History,WC-57, MRC-153, Washington, DC 20013-7012.E-mail: munroet@si.edu \\ ${ }^{2}$ Faculty of Fisheries, Nagasaki University, 1-14 Bunkyo, Nagasaki, 852-8521, Japan. E-mail: junh@net.nagasaki-u.ac.jp \\ ${ }^{3}$ Corresponding author.E-mail: munroet@si.edu
}

\begin{abstract}
Symphurus thermophilus n. sp., described from 16 specimens collected by submersibles, ROV, epibenthic sled and dredge, occurs on a variety of substrata at several active hydrothermal sites located at $239-733 \mathrm{~m}$ between $21^{\circ} \mathrm{N}$ and $35^{\circ} \mathrm{S}$ in the western Pacific Ocean. Symphurus thermophilus, the only pleuronectiform fish known to inhabit hydrothermal vent areas, is characterized by the combination of a 1-2-2-2-2 pattern of interdigitation of dorsal proximal pterygiophores and neural spines, 14 caudal-fin rays, 5 hypurals, 9 abdominal vertebrae, 47-51 total vertebrae, 88-94 dorsal-fin rays, 74-80 anal-fin rays, 100-112 scales in longitudinal series, ocular-side pigmentation pattern featuring 5-8, black, mostly incomplete crossbands, uniformly white blind side, and black peritoneum. Of specimens examined, seven including the holotype, were collected on Kaikata Seamount off southern Japan; one specimen was collected at the Kasuga-2 hydrothermal vent, Marianas Islands; and six were collected at sites on the Kermadec Ridge. In addition to specimens captured, many other $S$. thermophilus were observed from submersibles and ROVs at hydrothermal sites in the western Pacific including those in the Marianas Islands, at Nikko Seamount near Minami-Iohjima Island, and at Minami-Ensei Knoll, Mid-Okinawa Trough. Many of the specimens examined have skeletal anomalies including fused bones in the caudal skeleton, and missing or partially developed and/or misshapen fin rays.
\end{abstract}

Key words: flatfish, Symphurus, hydrothermal vents

\section{Introduction}

SPECIES of Symphurus Rafinesque are cynoglossid pleuronectiforms characterized by several distinct features (Chapleau 1988) including the absence of lateral sensory canals on the body, in having the anterior portion of the supraoccipital bone replaced by a cranial fontanelle, and in having a single pterygiophore inserted into the first interneural space (Munroe 1992). These species have been captured at various locations widely distributed throughout temperate and tropical regions of the Indo-West Pacific oceans (Alcock 1889a; Alcock 1894; Alcock 1899; Chabanaud 1954; Chabanaud 1955a; Chabanaud 1955b; Chabanaud 1955c; Chabanaud 1956; Munroe 1992; Munroe 2006; Munroe unpubl. data). In these waters, some 26 nominal species have been described and several undescribed species are known (Munroe unpubl. data) from capture depths ranging from $<1$ to about $1500 \mathrm{~m}$. The majority of Indo-West Pacific symphurine tonguefishes are small species (adult sizes usually smaller than ca. $100 \mathrm{~mm} \mathrm{SL}$ ) inhabiting substrata located in deep waters, usually at depths $>200$ m (capture depths summarized in Munroe 1992; see also Krabbenhoft \& Munroe 2003; Munroe 2006). Because of their depth of occurrence and relatively small size, many of these species have seldom been captured, and fewer still have been captured in any quantity. Therefore, for most species of Symphurus captured 
from deepwater habitats in the Indo-West Pacific (and from most deepwater locations worldwide), little detailed information is available concerning their microhabitat preferences and requirements, ecological distributions, population densities and spatial distributions, as well as many other aspects of their life histories.

Despite widespread occurrence of species of Symphurus throughout the Indo-Pacific region, none had ever been recorded from hydrothermally active regions until Hashimoto et al. (1988), Hashimoto et al. (1995) and others (Ono et al. 1996; Fujikura et al. 1998; Fujikura et al. 2002; Merle et al. 2004) observed numerous tonguefishes at several hydrothermal vent areas in the western Pacific. Sightings of tonguefishes in these physiologically-challenging environments represent the first and only recorded occurrences of symphurine tonguefishes at hydrothermal sites, and are also the only records for pleuronectiform fishes from hydrothermal sites worldwide (Biscoito et al. 2002; Biscoito 2006).

In earlier studies (Hashimoto et al. 1988; Hashimoto et al. 1995; Ono et al. 1996; Fujikura et al. 2002) tonguefishes captured or observed were provisionally identified as S. orientalis (Bleeker), while others (Fujikura et al. 1998; Merle et al. 2004) listed the species as an unidentified Symphurus. Seven of these tonguefish specimens were captured by the Japanese submersible Shinkai 2000 at the Kaikata Seamount site off southern Japan. Other specimens were observed and an individual captured at a hydrothermal vent site in the Marianas Islands (Merle et al. 2004) and several additional tonguefishes were recently collected with epibenthic sleds and submersible at hydrothermal vent sites on the Kermadec Arc off northern New Zealand. Detailed examination of these fishes reveals that they are not S. orientalis, but represent an undescribed species. The purpose of this paper is to provide a formal description for this species and to diagnose it from its congeners.

\section{Material and methods}

Type and non-type specimens are deposited in collections with institutional abbreviations as listed at http:// www.asih.org/codons.pdf. Description of this species is based on data from 16 specimens, including meristic, maturity and ecological data associated with a specimen (USNM 383313) from the Marianas Islands hydrothermal vent site that was partially dissected prior to being made available for inclusion in this study. Comparative material for all other Indo-Pacific species of Symphurus are detailed in Munroe (1992), Munroe and Marsh (1997), Krabbenhoft and Munroe (2003) and Munroe (2006).

Methods for counts and measurements and general terminology for systematics of tonguefishes follow Munroe (1998). Terminology for interdigitation patterns of proximal dorsal pterygiophores and interneural spines (ID pattern) follow that of Munroe (1992). ID patterns, fin ray and vertebral counts were made from radiographs. Since several specimens were missing fin rays or had fused vertebral centra (see Remarks), counts for these specimens were estimated to include the missing elements. Counts reported for specimens missing dorsal- and/or anal-fin rays included an estimated number of fin rays corresponding to the number of pterygiophores present that typically support these rays. Specimens with fused vertebrae were considered to have two vertebrae at each fusion site and are discussed further in the "Remarks" section.

Standard length (SL) and head length (HL) are used throughout. Measurements were made to the nearest $0.1 \mathrm{~mm}$ using either dial calipers or a dissecting stereo microscope fitted with a calibrated ocular micrometer. Morphometric features are expressed either as measurements in percentages of standard length (SL), or percentages of head length (HL). Descriptions of pigmentation are based on fishes fixed in formalin and stored in ethyl alcohol. Live color descriptions are based on fishes photographed or videotaped in situ. Estimates of size at maturity were determined based on ovarian development in females following criteria outlined in Munroe (1998).

Tonguefishes and other organisms were collected and habitat observations made via a series of surveys conducted aboard the R/V Kaiyo, the submersible Shinkai 2000, and her mother ship Natsushima, also on dive 
R794 of the ROV ROPOS during the R/V Thomas G. Thompson Cruise TN 167, during collecting by the R/V Tangaroa in the New Zealand Seamounts Programme, and with the submersible Pisces $V$ during NOAA's 2005 Ring of Fire Expedition to the Kermadec Ridge. Detailed observations on habitat characteristics, including physico-chemical data, were provided in Hashimoto et al. (1995), Fujikura et al. (1998), Merle et al. (2004) and literature cited therein.

\section{Symphurus thermophilus n. sp.}

(Figs. 1-3; Tables 1-2)

Symphurus cf. orientalis (not of Bleeker).-Hashimoto et al. 1988:87 (habitat observations from submersible Shinkai 2000 at 450-500 m, associated fauna; hydrothermal vent area, Kaikata Seamount near Bonin Island, western Pacific). Hashimoto et al. 1995:585 (photograph; microdistribution in depression C of hydrothermal vent area at about 715 m, Minami-Ensei Knoll, Mid-Okinawa Trough, western Pacific; based on submersible Shinkai 2000 observations; ecological observations also reported for specimens observed at 433-469 m from submersible Shinkai 6500, Nikko Seamount near Minami-Iohjima Island). Ono et al. 1996:223 (considered co-dominant species at vent communities at 428-733 m, Kaikata Seamount, Ogasawara (Bonin) Islands, western Pacific; density and biomass estimates based on submersible Shinkai 2000 and deep-tow TV system). Fujikura et al. 2002:24 (in Table 2; population density estimate at Minami-Ensei Knoll).

Symphurus sp.- Fujikura et al. 1998:134 (observations, photograph from submersible and ROV Dolphin 3K; member of obligate, vent-associated fauna at hydrothermal vent at 406 m near summit of Kasuga-2 Seamount, northern Marianas Trough, western Pacific). Biscoito et al. 2002:360 (Table 1; listed among fishes collected at active hydrothermal vent areas in Pacific Ocean). Merle et al. 2004:9, 42 (observations, photographs (Plate 2e, f) from ROV; numerous specimens on sedimentary habitats at 372-413 m on vent site of Kasuga-2 Seamount and at 378-403 m on Daikoku Seamount, northern Marianas Trough, western Pacific).

Holotype: NSMT-P 70849, female, $98.7 \mathrm{~mm}$ SL, Kaikata Seamount, 2k\# Station 888, 2642.30'N, $141^{\circ} 04.70^{\prime} \mathrm{E}, 440 \mathrm{~m}, 17$ Aug. 1996, collected with submersible Shinkai 2000 suction sampler, J. Hashimoto collector.

Paratypes: 7 specimens. NSMT-P 70850, 2 females, 78.4-100.8 mm SL (collected with holotype); USNM 383312, 2 females, 77.3-101.7 mm SL (collected with holotype); NSMT-P 70851, 1 female, $82.5 \mathrm{~mm}$

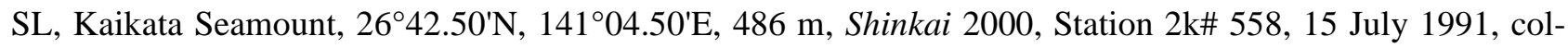
lected with submersible Shinkai 2000 suction sampler, J. Hashimoto collector; USNM 383311, 1 female, 61.8

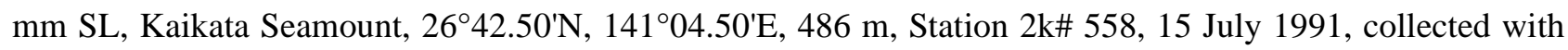
submersible Shinkai 2000 suction sampler, J. Hashimoto collector; NMNZ P.38300, 1 male, $87.1 \mathrm{~mm}$ SL, Kermadec Ridge, Rumble 3 Submarine volcano outer Bay of Plenty, 35 $44.22^{\prime}-44.04$ 'S, $178^{\circ} 29.72-29.63^{\prime} \mathrm{E}$, 239-270 m, 21 May 2001, collected with epibenthic sled by R/V Tangaroa.

Additional non-type specimens examined: 8 specimens. USNM 383313, 1 female, $47.5 \mathrm{~mm}$ SL, Marianas Islands, Station 794-SS-J1-004 at Kasuga-2 site at Barnacle Boulders, $21^{\circ} 36.52^{\prime} \mathrm{N}, 143^{\circ} 38.17^{\prime} \mathrm{E}, 393 \mathrm{~m}$, 12 April 2004, collected by ROV ROPOS (dive R794), R/V Thomas G. Thompson Cruise TN 167 (Chief Scientist R.W. Embley), S. K. Juniper and K. Tamburri collectors; NMNZ P.38141, 1 female, $60.8 \mathrm{~mm}$ SL and 1 male, $40.9 \mathrm{~mm}$ SL, Kermadec Islands, summit of Macauley Cone, $30^{\circ} 12.73 \mathrm{~S}$, $178^{\circ} 26.77^{\prime} \mathrm{W}, 280 \mathrm{~m}$, April 2002, collected with dredge by R/V Tangaroa; NMNZ P.41940, 2 males, 75.5 and 91.5 mm SL, Kermadec Islands, Macauley Cone, Macauley Island, 30² $12.78^{\prime} \mathrm{S}, 178^{\circ} 26.95^{\prime} \mathrm{W}, 338 \mathrm{~m}, 14$ April 2005, collected with submersible Pisces $V$ suction sampler, T. Kirby collector; NMNZ P.42748, 2 males, 65.5 and $77.0 \mathrm{~mm}$ SL, Kermadec Islands, Macauley Cone, Macauley Island, 30²12.78'S, 178²6.94'W, 338 m, 14 Apr 2005, collected with submersible Pisces $V$ suction sampler, T. Kirby collector; NMNZ P. 42747, 1 male, 88.4 mm SL, Kermadec Islands, Macauley Cone, Macauley Island, 30 ${ }^{\circ} 12.78^{\prime} \mathrm{S}, 178^{\circ} 26.89^{\prime} \mathrm{W}, 260 \mathrm{~m}, 14$ Apr 2005, collected with submersible Pisces $V$ suction sampler, T. Kirby collector. 
Diagnosis. Symphurus thermophilus is distinguished from congeners by the combination of: a 1-2-2-2-2 ID pattern, 14 caudal-fin rays, 9 abdominal vertebrae, 47-51 total vertebrae, 5 hypurals, 88-94 dorsal-fin rays, 74-80 anal-fin rays, 47-56 scales in a transverse series, 100-112 scales in a longitudinal series, black peritoneum, medium to dark brown ocular-surface background pigmentation with distinct pattern of darker blotches and complete and incomplete crossbands, and a uniformly whitish blind side.

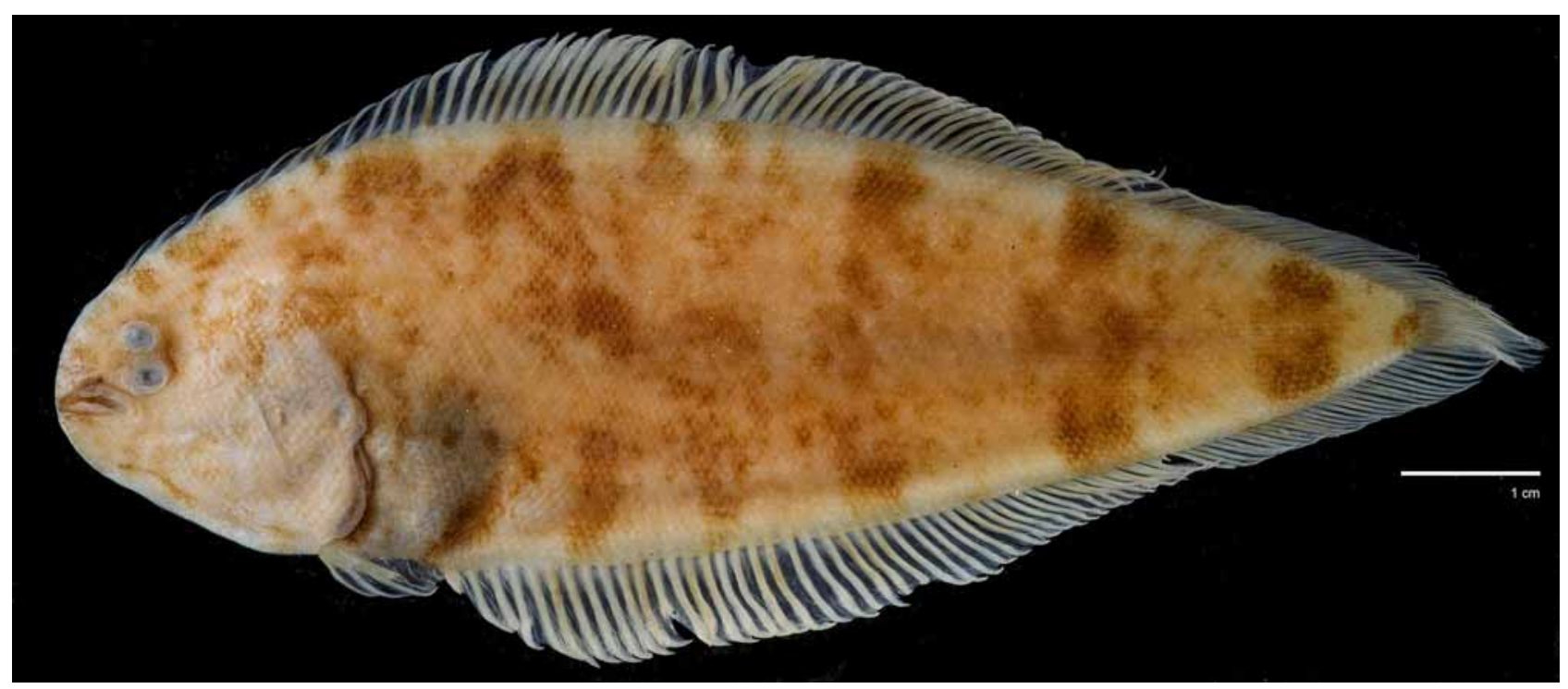

FIGURE 1. Ocular-side view of Symphurus thermophilus, new species, holotype NSMT-P 70849, $98.7 \mathrm{~mm}$ SL, adult female, collected at $440 \mathrm{~m}$ on Kaikata Seamount, Minami-Ensei Knoll, Mid-Okinawa Trough, Western Pacific, 17 August 1996.

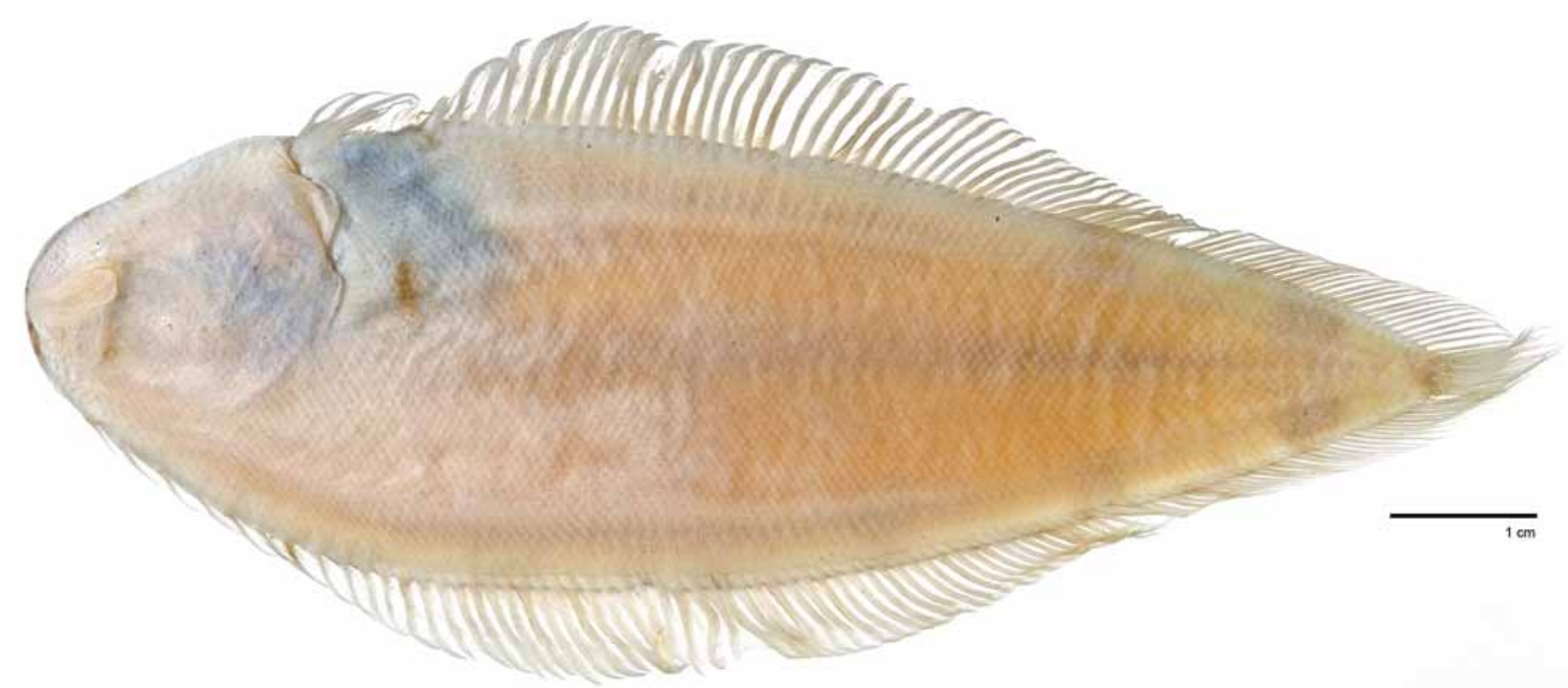

FIGURE 2. Blind-side view of holotype of Symphurus thermophilus, new species, holotype NSMT-P 70849, 98.7 mm SL, adult female collected at Kaikata Seamount, Minami-Ensei Knoll, Mid-Okinawa Trough, Western Pacific.

Description. A diminutive species attaining maximum sizes of about $102 \mathrm{~mm}$ SL. Summaries of meristic data appear in Table 1 (see also Remarks section below). ID pattern 1-2-2-2-2 (15/16), rarely 1-2-2-1-2. Caudal-fin rays 14. Dorsal-fin rays 88-94. Anal-fin rays 74-80. Pelvic-fin rays 4. Total vertebrae 47-51 (usually $48-50)$; $9(3+6)$ abdominal vertebrae $(15 / 16$ individuals), rarely $10(3+7$; one individual). Hypurals usually 5 (one specimen each with 4 or 6 hypurals). Longitudinal scale rows 100-112. Scale rows on head posterior to lower orbit 20-24. Transverse scales 47-56. 
TABLE 1. Summary of meristic features for the holotype (NSMT-P 70849) and 15 other specimens of Symphurus thermophilus. Asterisk indicates value for holotype. ID pattern represents insertion arrangement for five anteriormost proximal dorsal-fin pterygiophores in the anteriormost interneural spaces. Footnotes refer to specimens with missing meristic elements for which counts are estimated (See Methods and Remarks).

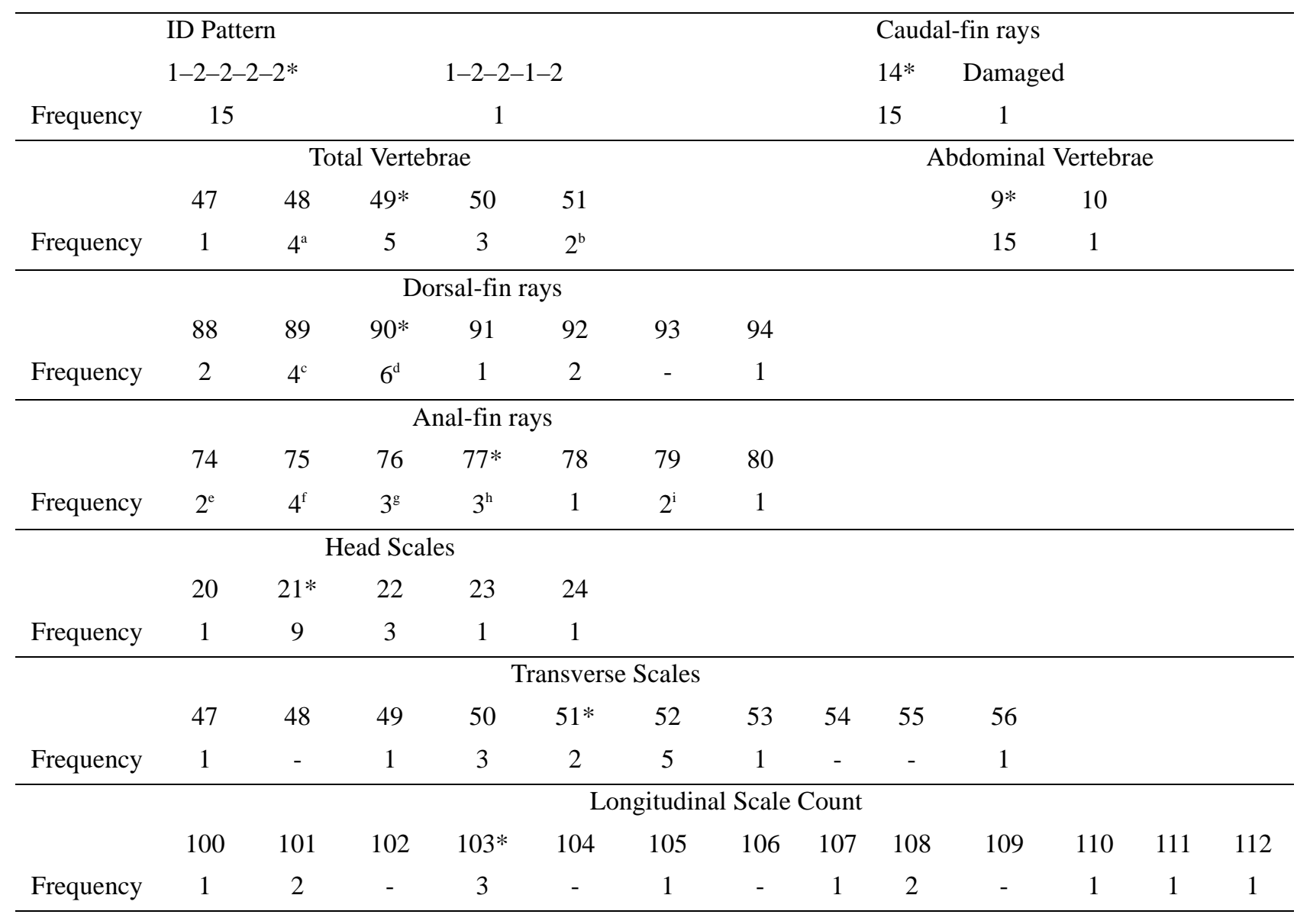

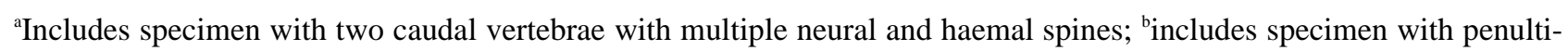
mate caudal vertebrae with two neural spines; includes specimen missing 10 fin rays; includes counts for holotype

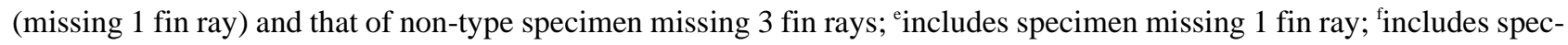
imen missing 1 fin ray and estimated count for second specimen missing 2 fin rays and with approximately 4 other fin rays removed during dissection prior to this study); ${ }^{g}$ includes specimen missing 1 fin ray; hincludes count for holotype which is missing 1 fin ray; includes counts for one specimen missing 2 fin rays and one specimen missing 3 fin rays.

Proportions of morphometric features are presented in Table 2. Body notably deep (Fig. 1), with greatest depth in anterior third of body usually at point between anus and fourth to sixth anal-fin ray, followed by gradual taper in posterior two-thirds of body. Preanal length shorter than body depth. Head moderately long and bluntly pointed in anterior profile; head wide; head width slightly narrower than body depth. Head length noticeably shorter than head width; HW/HL=1.18-1.30 $(\overline{\mathbf{X}}=1.24)$. Upper head lobe width usually slightly greater than postorbital length. Lower head lobe usually narrower than upper head lobe; lower opercular lobe usually wider than upper opercular lobe and with its posterior margin projecting slightly beyond posterior margin of upper opercular lobe. Snout bluntly pointed; moderately long; with scales covering anterior region. Dermal papillae well developed on blind-side snout, lower lip, chin (extending posteriorly to about area at posterior margin of jaws), and on dorsal margin of head along bases of anteriormost dorsal-fin rays; dermal papillae not as well developed on smaller specimens; dermal papillae most dense on snout and around lower lip and with dense band extending posteriorly along dorsal margin of head to point about equal with vertical through dorsal-fin origin. Anterior nostril on ocular side relatively short, when depressed posteriorly not 
reaching anterior margin of lower eye. Anterior nostril on blind side shorter than ocular-side counterpart, but conspicuous among dermal papillae on snout. Jaws long and slightly arched; upper jaw length larger than snout length; maxilla usually extending posteriorly to point between verticals through anterior margin and midpoint of pupil of lower eye. Ocular-side lower jaw without fleshy ridge. Cheek depth about equal with, or slightly greater than, snout length. Eyes relatively large and round, with conspicuous pupil whose diameter equals about $72 \%$ of eye diameter in the holotype (55-68\% of ED in six other specimens examined); eyes subequal in position with upper slightly in advance of lower eye. Pupillary operculum absent. Anterior and medial surfaces of eyes and narrow interorbital space covered with about five to seven rows of small, ctenoid scales. Dorsal-fin origin anteriorly placed, with anteriormost dorsal-fin ray usually at point between verticals through anterior margin and midpoint of pupil of upper eye; predorsal length moderately long. Anteriormost dorsal-fin rays slightly shorter than more posterior fin rays. Scales absent on ocular and blind sides of dorsaland anal-fin rays. Pelvic fin moderately long; longest pelvic-fin ray, when extended posteriorly, usually reaching base of first, sometimes second, anal-fin ray. Posteriormost pelvic-fin ray broadly connected to body and to urogenital papilla by delicate membrane. Caudal fin relatively long. Teeth present and recurved slightly inwards on ocular- and blind-side jaws; teeth better developed on blind-side jaws. Ocular-side premaxilla with two to three short rows of teeth narrowing to a single row of teeth in middle and posterior regions. Ocular-side dentary with single row of sharply pointed teeth. Blind-side premaxilla with four to five rows of recurved teeth, those on anterior jaw slightly longer than others. Blind-side lower jaw with four to five rows of recurved teeth with anterior teeth about same size as those on posterior jaw. Scales small and numerous, strongly ctenoid on both sides of body.

TABLE 2. Morphometrics for holotype (NSMT-P 70849) and 14 additional specimens of Symphurus thermophilus. SL in $\mathrm{mm}$; characters 2-9 in percent SL; 10-17 in percent HL.

\begin{tabular}{lccccc}
\hline & Character & Holotype & \multicolumn{3}{c}{ Other Specimens } \\
& & & Range & Mean & SD \\
\hline 1 & Standard Length & 98.7 & $40.9-101.7$ & 77.8 & 16.58 \\
2 & Body depth & 31.7 & $28.4-33.1$ & 30.3 & 1.42 \\
3 & Preanal length & 28.0 & $24.8-27.9$ & 26.6 & 8.66 \\
4 & Caudal-fin length & 11.9 & $7.4-12.2$ & 9.9 & 1.33 \\
5 & Head length & 23.2 & $21.6-23.2$ & 22.3 & 0.76 \\
6 & Head width & 28.5 & $26.2-29.3$ & 27.5 & 1.03 \\
7 & Upper head lobe & 15.5 & $13.8-17.1$ & 15.4 & 0.88 \\
8 & Lower head lobe & 14.5 & $11.7-15.9$ & 14.1 & 1.17 \\
9 & Postorbital length & 14.6 & $13.1-15.7$ & 14.4 & 0.68 \\
10 & Snout length & 20.5 & $17.4-24.6$ & 21.1 & 1.92 \\
11 & Upper jaw length & 28.8 & $21.9-30.8$ & 27.0 & 2.21 \\
12 & Eye diameter & 10.5 & $10.2-16.3$ & 13.2 & 1.79 \\
13 & Cheek depth & 20.5 & $18.5-28.1$ & 22.3 & 2.49 \\
14 & Opercular lower lobe & 35.8 & $26.9-36.4$ & 32.3 & 3.13 \\
15 & Opercular upper lobe & 28.8 & $21.7-36.4$ & 28.7 & 4.45 \\
16 & Predorsal length & 24.9 & $24.2-31.9$ & 27.7 & 2.49 \\
17 & Postorbital length & 62.9 & $58.9-69.9$ & 64.6 & 2.84 \\
18 & Head width/Head length & 1.23 & $1.18-1.30$ & 1.24 & 0.041 \\
19 & Pupil/Eye diameter & 0.72 & $0.55-0.68$ & 0.62 & 0.050 \\
\hline
\end{tabular}




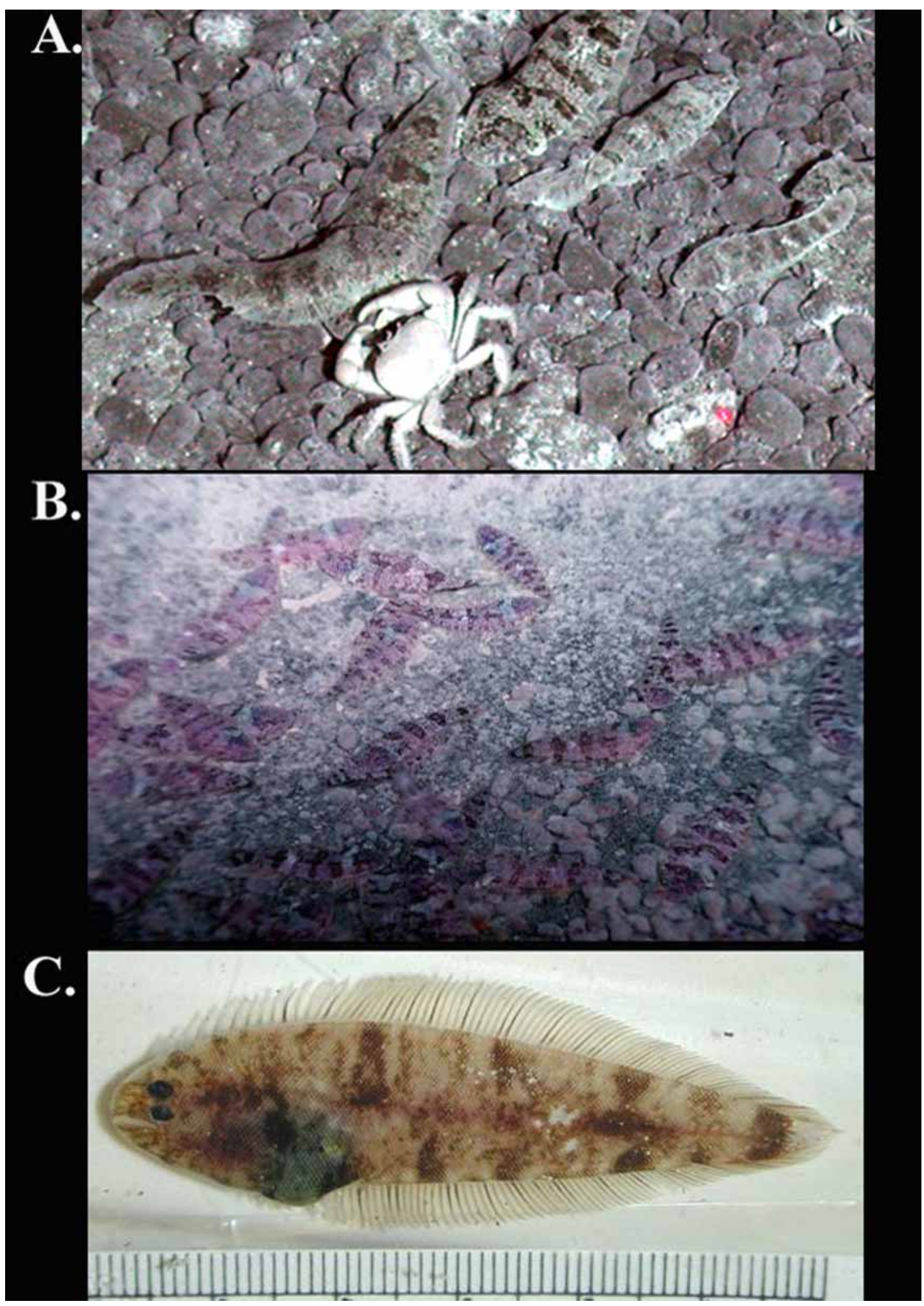

FIGURE 3. Photographs of the hydrothermal vent tonguefish, Symphurus thermophilus. A. In situ photograph of S. thermophilus observed at Rumble 3 site, western Pacific, an area where this species occurs in high abundance. B. In situ photograph of $S$. thermophilus (most individuals $<10 \mathrm{~cm}$ TL) observed at Daikoku Seamount, western Pacific, an area where this species occurs in high abundance. C. Photo of recently captured juvenile $S$. thermophilus taken at the Barnacle Boulders site at Kasuga-2, Mariana Islands. Figures 3A-C provided courtesy of NOAA's Ocean Exploration Program and available from http://oceanexplorer.noaa.gov/gallery/livingocean/livingocean_fish.html\#fish (Accessed 3 June 2008) and http://oceanexplorer.noaa.gov/explorations/06fire/logs/hires/tonguefish_crabs_nikko_hires.jpg (Accessed 3 June 2008) 
Color in alcohol. Body coloration generally similar for adult and juvenile specimens (Figs. 1; 3). Ocular surface of head and body (Fig. 1) with medium to dark chocolate-brown background coloration, with five to eight distinctively darker, complete and incomplete (mostly), black crossbands, and with numerous, black, irregularly-shaped blotches scattered across ocular surface. Abdominal area immediately posterior to opercular opening blackish-brown, much darker than general body color; some specimens also with darker pigmented patch located antero-ventrally on abdomen just posterior to gill opening. Crossbands usually darkest on body regions overlying dorsal- and anal-fin pterygiophores. Crossbands begin on snout in region immediately anterior to eyes and extend posteriorly along body with posteriormost crossband located just anterior to base of caudal fin. Most crossbands in midbody region incomplete. Some crossbands continued onto dorsal and anal fins as pigmented blotches. Ocular-side snout region with similar coloration to that on body. Outer surface of ocular-side opercle with coloration similar to background color on body, except posterior opercular margin usually darker than anterior opercular regions. Inner linings of both opercles variously speckled, with that of ocular side usually with more and darker speckles than blind-side counterpart. Both sides of isthmus usually unpigmented, sometimes with light speckling on one (usually ocular) or both sides. Linings of oral cavity not darkly pigmented. Both lips usually darkly pigmented over their entire lengths.

Blind side of head and body (Fig. 2) uniformly white; some specimens with scattered dark patches of melanophores on blind-side body scales, more so on scales near bases of dorsal and anal fins. Usually with small group of melanophores clustered around anus. Peritoneum black, showing through abdominal wall on both sides of body. Some specimens also with conspicuous row of deep, internal, melanophores along longitudinal body midline on blind side.

Fin rays of dorsal and anal fins with alternating series of pigmented blotches and lighter areas. Blotches in dorsal and anal fins extending over entire length of fin rays and covering about 5-7 fin rays, separated by intervening lightly pigmented areas of about equal width to that of blotches. Ocular side of caudal fin with dark, conspicuous spot at its base and with fin rays darkly pigmented throughout their lengths. Blind side of caudal fin also with dark pigmented spot at its base, otherwise blind side of caudal-fin rays uniformly whitish.

Live coloration (Figs. 3A-C). Ocular surface of head and body with medium- to dark- chocolate brown background coloration, overlain with five to eight distinctively darker, complete and incomplete (mostly) crossbands, and mottled with numerous, dark, irregularly-shaped blotches and whitish speckles scattered across entire ocular surface. Ocular surface of some individuals also with a conspicuous white patch overlying anterior two-thirds of abdominal cavity. Medial, and sometimes entire surface, of white abdominal patch highlighted with bluish-green tints and bordered ventro-posteriorly by black, sometimes nearly rectangular, blotch. Abdominal area immediately posterior to opercular opening blackish-brown, much darker than general body color; some specimens also with one or two darker pigmented patches located antero-ventrally on abdomen just posterior to gill opening. Some individuals with one or two, irregular to nearly subspherical, conspicuous white spots (aligned longitudinally when two spots present) on body midline just posterior to body midpoint. Medial white spots as large as eye diameter when two present, or about twice eye diameter when only single spot present. Crossbands usually darkest on body regions overlying dorsal- and anal-fin pterygiophores, but not continued onto dorsal and anal fins. Crossbands begin on snout in region immediately anterior to eyes and extend posteriorly along body with posteriormost crossband located just anterior to base of caudal fin. Most crossbands in midbody region incomplete; posteriormost two or three crossbands usually complete and sometimes darker than others. Ocular-side snout region with similar coloration as that of body. Lip of upper jaw of some specimens usually more darkly pigmented than lip of lower jaw. Outer surface of ocular-side opercle with similar coloration to background color on body, except posterior opercular margin usually more darkly pigmented than anterior regions and opercle with black pigmented area at its dorso-posterior angle. Black peritoneum not nearly as prominent as in preserved fishes, only showing through ocular-side abdominal wall in some individuals. 
Ocular sides of dorsal-, anal-, pelvic- and caudal-fin rays generally with darkly-pigmented band proximally and with fin-ray tips distally lighter in color. Distal tips of some dorsal- and anal-fin rays (usually those in middle of body) of some individuals conspicuously whitish. Ocular side of caudal fin generally with dark, conspicuous, irregular spot at its base and with fin rays darkly pigmented proximally.

Size and sexual maturity. A diminutive-sized species of Symphurus, attaining standard lengths to at least $102 \mathrm{~mm}$. Of 16 specimens examined, nine are females ranging in size from 47.5 to $101.7 \mathrm{~mm}$ SL; males range in size from 40.9-91.5 mm SL. Six females (77.3, 78.4, 82.5, 98.7, 100.8 and $101.7 \mathrm{~mm} \mathrm{SL})$ are mature with elongate ovaries, but without obvious signs of developed ova. The three smallest females, measuring 47.5$61.8 \mathrm{~mm} \mathrm{SL}$, are immature. The two largest of these have elongate ovaries, but these are considerably narrower and shorter than ovaries of other females indicating these specimens were approaching maturation. The smallest female examined (USNM 383313), collected at the Kasuga-2 site, is $47.5 \mathrm{~mm}$ SL and has the ovaries only partially elongate indicating the onset of sexual maturation. Based on ovarian elongation in the nine females, sexual maturation in this species is estimated to occur at sizes of about $62 \mathrm{~mm}$ SL and larger.

Distribution. An endemic species in the western Pacific Ocean collected at several active hydrothermal vent sites with a disjunct distribution over a wide geographic range from Kaikata Seamount $\left(26^{\circ} 42.30^{\prime} \mathrm{N}\right.$, $141^{\circ} 04.70^{\prime} \mathrm{E}$; near Bonin Island, off southeastern Japan) to the Rumble 3 Submarine Volcano $\left(35^{\circ} 44^{\prime} \mathrm{S}\right.$, $178^{\circ} 72-79^{\prime} \mathrm{W}$ ) on the Kermadec Ridge, northern New Zealand (Fig. 4). Symphurus thermophilus has been collected or observed on sedimentary habitats at Kaikata Seamount near Bonin Island at 428-733 m (Ono et al. 1996); at 433-469 m on Nikko Seamount near Minami-Iohjima Island (based on submersible observations; cited as person. commun. in Hashimoto et al. 1995); and at about $715 \mathrm{~m}$ at Minami-Ensei Knoll, Mid-Okinawa Trough (based on submersible observations; Hashimoto et al. 1995). Fujikura et al. (1998) observed numerous individuals at $406 \mathrm{~m}$ near the summit of the Kasuga-2 Seamount in the northern Marianas Islands $\left(21^{\circ} 36.52^{\prime} \mathrm{N}, 143^{\circ} 38.17^{\prime} \mathrm{E}\right)$, and Merle et al. (2004) collected a specimen at $393 \mathrm{~m}$ and observed many other specimens (see Fig. 3B) at 372-413 m during dives conducted by the ROV ROPOS at the Barnacle Boulders site on the Kasuga-2 Seamount. This species was also observed at Daikoku Seamount (Fig. 3) at similar depths (378-403 m; observations summarized in Merle et al. 2004). Symphurus thermophilus has also been collected and observed (Fig. 3A) at the Rumble 3 Submarine Volcano (35 44.22'-44.04'S, $178^{\circ} 29.72$ $\left.29.63^{\prime} \mathrm{E}\right)$ and Macauley Submarine Volcano $\left(30^{\circ} 12.73^{\prime} \mathrm{S}, 178^{\circ} 26.71^{\prime} \mathrm{W}\right)$ on the Kermadec Ridge at sites somewhat shallower (239-338 m) than those in the northern reaches of its distribution.

The disjunct distribution of collections and observations of $S$. thermophilus most likely reflects sampling efforts of investigators, which have been concentrated at only a few of the many hydrothermal vent sites between the distalmost points in the geographic range noted above. It may be expected that $S$. thermophilus will be found at intervening hydrothermal vent sites located at appropriate depths when these are explored.

Ecology. Symphurus thermophilus occurs on a variety of substrata only within active hydrothermal vent sites located at depths between about 239 and $733 \mathrm{~m}$ (Figs. 3A-3B). These tonguefishes were observed on coarse sand bottoms at Kaikata Seamount on the Izu-Ogasawara Arc (near Bonin Islands) off southern Japan by Hashimoto et al. (1988). At Kaikata Seamount, S. thermophilus occurred in such high densities that some individuals overlapped one another on the coarse sandy bottom where shimmering water of ca. $19-22^{\circ} \mathrm{C}$ was percolating upwards through the sediments (Hashimoto et al. 1988). Ono et al. (1996) indicated that this species mainly inhabited yellow-colored substrata in the vent area they studied on Kaikata Seamount located at about $450 \mathrm{~m}$. Hashimoto et al. (1995) record this species at $715 \mathrm{~m}$ on whitish metachromatic sediments of active hydrothermal vent sites in depression $\mathrm{C}$ on the Minami-Ensei Knoll, Mid-Okinawa Trough, where lowtemperature hydrothermal fluids ca. $5-10^{\circ} \mathrm{C}$ higher than the ambient seawater percolated from the sandy bottom. At Kasuga-2 Seamount in the northern Marianas Trough, tonguefishes were also observed in abundance on sedimentary fields covered with whitish bacterial mats at vent sites located at approximately $406 \mathrm{~m}$ (Fujikura et al. 1998). Merle et al. (2004) also record numerous specimens of this species on a variety of dark and lighter-colored sand and coarse gravel sediments at Kasuga-2 site (see Fig. 3B) and Daikoku Seamounts 
$\left(21^{\circ} 19^{\prime} \mathrm{N}, 144^{\circ} 12^{\prime} \mathrm{E}\right)$ on the Mariana Volcanic Arc. Both adults and juveniles are found in the same habitats (see comments in Merle et al. 2004; this study).

At the hydrothermal site at Kaikata Seamount where $S$. thermophilus is abundant, Ono et al. (1996), based on continuous video images taken by the Shinkai 2000, estimated population densities of 2.48 individuals $/ \mathrm{m}^{2}$ and estimated biomass of tonguefishes at this site at $17.3 \mathrm{~g} / \mathrm{m}^{2}$. Tonguefishes were about twice as numerous (4.5 individuals $\left./ \mathrm{m}^{2}\right)$ on yellow-colored substrata as they were on white-colored substrata $\left(2.3\right.$ individuals $\left./ \mathrm{m}^{2}\right)$. Fujikura et al. (2002) estimated population densities at Minami-Ensei Knoll at $>0.1$ individuals $/ \mathrm{m}^{2}$.

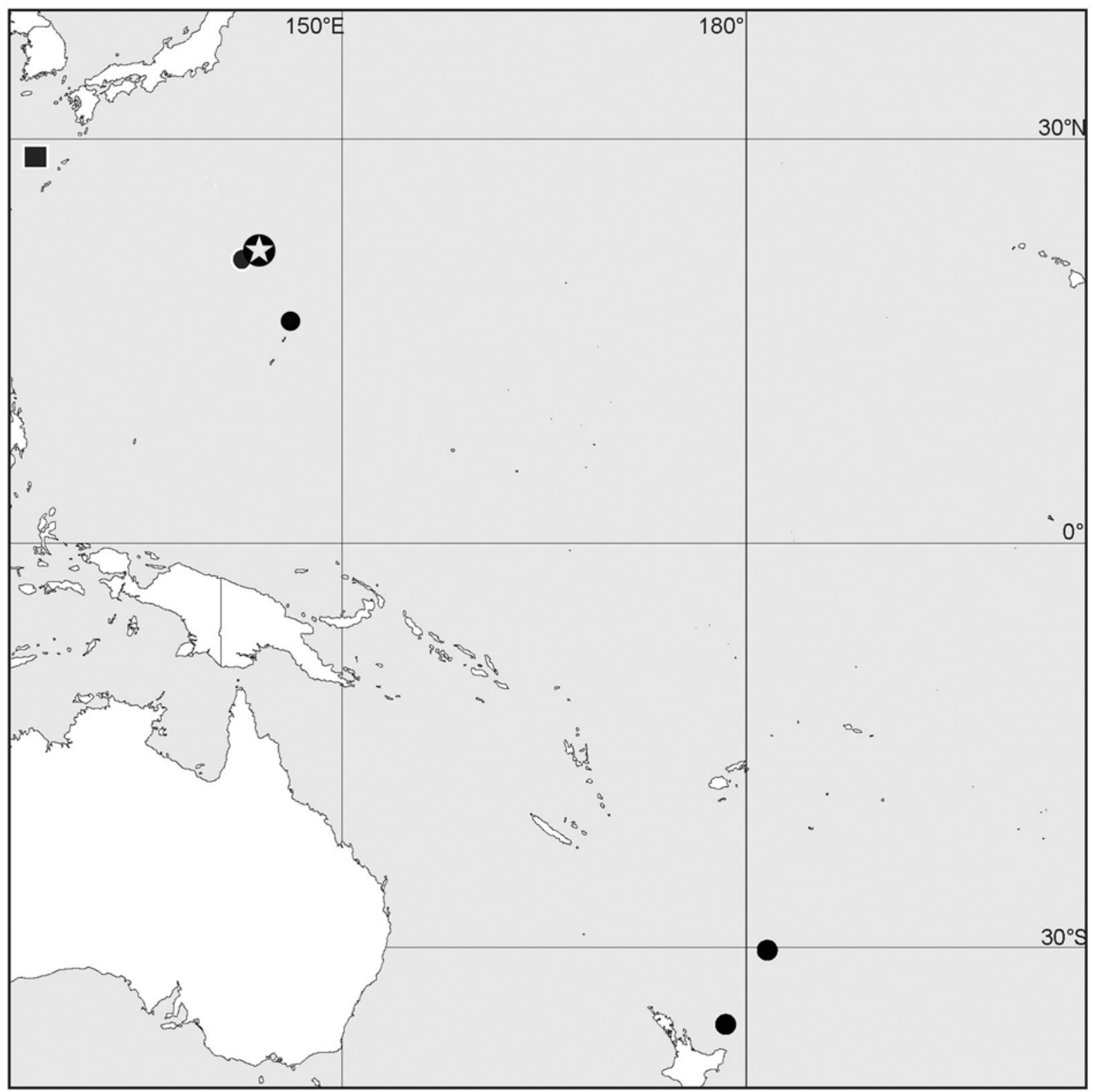

FIGURE 4. Capture locations for holotype (indicated by star) and other specimens (indicated by black circles) of Symphurus thermophilus examined in this study. Another locality where species has also been observed is indicated by the black square.

Etymology. From the Greek thermos meaning heat and philos meaning lover. In reference to the preferred habitat of this species at active hydrothermal vent areas.

Remarks. Fifteen of the 16 specimens of $S$. thermophilus have a 1-2-2-2-2 ID pattern; the outlier has a 1-2-2-1-2 ID pattern, which is not an unusual pattern in other species of Symphurus characterized by a 1-22-2-2 ID pattern (Munroe 1992). One of 16 specimens of $S$. thermophilus examined has 10 abdominal verte- 
brae; all others have nine. Within the genus Symphurus, only 5 of 73 species possess 10 abdominal vertebrae, whereas all others have nine abdominal vertebrae (Munroe 1992). Abdominal vertebral number is among the most conservative of skeletal features used to diagnose species of Symphurus and it is rare to observe even a single instance of intraspecific variability with regard to this character (Munroe 1992; Munroe 1998).

Many of the specimens examined have skeletal anomalies including fused bones in the caudal skeleton, and missing or partially developed and/or misshapen fin rays. Two of 16 specimens have fused caudal vertebrae evidenced by presence of multiple neural and haemal spines on a centrum. In symphurine tonguefishes, each centrum has only a single neural and haemal spine, except for the PU2 centrum, which sometimes may have a double set of neural and/or haemal spines (see below). Presence of multiple neural and haemal spines on a caudal centrum, therefore, usually indicates that some unknown number of vertebrae fused or failed to separate during ontogeny. One $S$. thermophilus anomalously has multiple neural and haemal spines on caudal centra at two different sites in the mid-vertebral column. Since multiple neural and haemal spines are present on both centra, it is difficult to accurately interpret the number of vertebrae involved at each site. Conservatively, estimating only two vertebrae involved in each fusion renders a vertebral count of 48 , which is within the range recorded for other $S$. thermophilus (Table 1).

The second specimen has the PU2 centrum with two neural and two haemal spines. Presence of double neural and/or haemal spines on the PU2 centrum occurs among individuals of other species of Symphurus (Munroe \& Mahadeva 1989; Munroe unpubl. data) and other Pleuronectiformes (Rosen 1973; Hensley \& Ahlstrom 1984; Chanet \& Wagemans 1997). In S. callopterus, for example, 27 of 180 specimens examined have the PU2 or PU3 centrum with double neural and/or haemal spines (Munroe \& Mahadeva 1989). Presence of double neural or haemal spines results from fusion or lack of differentiation and separation of two vertebrae, which appears to be the case in this specimen of $S$. thermophilus.

Comparisons. Symphurus thermophilus belongs to the species group within Symphurus characterized by a 1-2-2-2-2 ID pattern of proximal dorsal pterygiophores and neural spines (Munroe 1992). All but two of the species featuring this ID pattern occur in the Indo-West Pacific region. Within Symphurus, in addition to $S$. thermophilus, 18 other species have a combination of 14 caudal-fin rays and either a 1-2-2-2-2 or 1-2-2-12 ID pattern (Munroe 1992; Krabbenhoft \& Munroe 2003; Munroe 2006). All but S. bathyspilus Krabbenhoft and Munroe, S. monostigmus Munroe, S. woodmasoni (Alcock), S. macrophthalmus Norman, and S. schultzi Chabanaud have higher and non-overlapping meristic features (dorsal-fin rays $>95$; anal-fin rays usually $>80$; total vertebrae 53 or more) than those found in S. thermophilus.

Among congeners with overlapping meristic features, S. thermophilus has some similarity with the meristic features and has the same ID pattern as those found in $S$. bathyspilus, which has been collected in deepwaters near the Philippines and Indonesia (Krabbenhoft \& Munroe 2003), and S. monostigmus taken in 65-110 m off KwaZulu-Natal, East Africa (Munroe 2006). Symphurus thermophilus differs from S. bathyspilus in features of its ocular-side pigmentation (S. thermophilus with uniformly white blind side versus blind side with pattern of red speckles, especially in regions overlying pterygiophores of dorsal and anal fins in S. bathyspilus; dorsal and anal fins of $S$. thermophilus with an alternating series of prominent pigmented blotches and lighter areas and caudal fin with prominent conspicuous spot at its base and with caudal-fin rays darkly pigmented throughout their lengths versus dorsal and anal fins of $S$. bathyspilus more or less dark brown and becoming lighter posteriorly, with the caudal fin often colorless). Symphurus thermophilus has more scales in a longitudinal series (100-112) compared with the 76-92 scale rows of S. bathyspilus. Counts for dorsal- and anal-fin rays range higher in S. bathyspilus (91-100 and 78-87, respectively) than those of S. thermophilus. These two species also differ in many other aspects of their morphology: S. thermophilus has a deeper body (BD 28.4-33.1\% SL versus 21.8-25.8\% in S. bathyspilus), shorter caudal fin (7.4-12.2\% SL versus 11.119.5\%), wider head (26.2-29.3\% SL versus 20.6-26.2\%) much wider than its length (HW/HL $=1.18-1.30(\bar{X}$ $=1.24$ ) versus $0.99-1.03$ ( $\overline{\mathrm{X}}=1.03)$ in S. bathyspilus $)$, wider upper head lobe $(13.8-17.1 \%$ SL versus $8.9-$ 
13.0\%), wider lower head lobe (11.7-15.9\% SL versus 10.1-14.0\%), longer snout (17.4-24.6\% HL versus 12.9-19.7\%) and longer upper jaw (21.9-30.8\% HL versus 19.0-24.5\%) compared with those features of $S$. bathyspilus.

Symphurus thermophilus differs distinctively from S. monostigmus from the western Indian Ocean in at least two features of its pigmentation including: dark brown ocular-side pigmentation with complete and incomplete crossbands and dark blotches (versus light yellowish-white and freckled ocular-side pigmentation pattern with prominent black spot overlying anteroventral region of abdominal cavity characteristic of $S$. monostigmus), and S. thermophilus has a uniformly black peritoneum (versus peritoneum unpigmented anteriorly, spotted in mid-region, and black only in posterior region in S. monostigmus). Symphurus thermophilus also differs in several morphometric features from those of $S$. monostigmus including: a longer preanal length (24.8-28.0\% SL versus 21.3-25.5\% in S. monostigmus), shorter caudal fin (7.4-12.2\% SL versus 13.2$13.3 \%$ ), longer head length (21.6-23.2\% SL versus 17.8-20.2\%), head much narrower than its length (HW/ $\mathrm{HL}=1.18-1.30$ versus $\mathrm{HW} / \mathrm{HL}=1.39-1.42$ in $S$. monostigmus $)$, wider lower head lobe $(11.7-15.9 \%$ SL versus 10.9-12.1\%) and longer snout (17.4-24.6\% HL versus $14.5-17.2 \%)$.

Symphurus thermophilus differs from $S$. woodmasoni, known from several specimens collected on soft sediments (substratum comprised of red-brown ooze) in deepwater (at ca. $865 \mathrm{~m}$ ) off the Indian subcontinent in the Bay of Bengal and Andaman Sea (Alcock 1889a; Alcock 1892; Alcock 1894), in having 47-51 total vertebrae (versus 55 in $S$. woodmasoni), and different scale counts (S. thermophilus with 100-112 scales in longitudinal series and 47-56 scales in transverse series versus $S$. woodmasoni with ca. 85 scales and 34 scales in longitudinal and transverse series, respectively). Symphurus thermophilus usually has a 1-2-2-2-2 ID pattern (versus 1-2-2-1-2 in S. woodmasoni) and 9 (versus 10) abdominal vertebrae. Symphurus thermophilus also differs from $S$. woodmasoni in several pigmentation features, the most notable of which is its uniformly white blind side (see Fig. 2) (versus both sides of body bluish-gray in $S$. woodmasoni). The two species differ in that $S$. thermophilus has a conspicuous series of incomplete and complete crossbands on its ocular surface, whereas $S$. woodmasoni has a uniformly pigmented ocular side without crossbands. Symphurus thermophilus lacks the broad, blue-black bands overlying pterygiophore regions on each side of the body (present in $S$. woodmasoni), lacks the numerous parallel black lines extending longitudinally through the middle of each row of scales from the snout to the caudal region that are present in $S$. woodmasoni, and the opercle of $S$. thermophilus is not as intensely pigmented as that of S. woodmasoni. Additionally, S. thermophilus has a series of pigmented blotches alternating with unpigmented areas on the dorsal and anal fins in contrast to the more or less uniformly black dorsal and anal fins of $S$. woodmasoni, and the caudal fin of S. thermophilus has a distinct black pigmented band on its ocular-side base with the distal regions only lightly pigmented versus the solid grey caudal fin of $S$. woodmasoni.

Symphurus thermophilus is also similar to $S$. schultzi (based on holotype and 4 paratypes), a deepwater species from the western Pacific Ocean (Chabanaud 1955b), including number of caudal-fin rays (14) and total vertebrae (48-50 for S. schultzi; see Chabanaud (1955b) and Munroe (1992) for data), and both species feature a prominent black peritoneum observed through the abdominal wall on both sides of the body. Though sharing these similarities, $S$. thermophilus differs distinctively from this species in its ID pattern (1-2-2-2-2 versus four paratypes of $S$. schultzi with a 1-2-2-1-2 ID pattern; holotype with 1-2-2-2-2 ID pattern) and $S$. thermophilus has 100-112 scales in a longitudinal series versus ca.70-80 in S. schultzi. Symphurus thermophilus also has higher, though partially overlapping, dorsal- (88-94 versus 85-88 in S. schultzi) and anal-fin ray (74-80 versus 72-75 in $S$. schultzi) counts compared with those of $S$. schultzi. Symphurus thermophilus may also differ in color pattern compared with that of $S$. schultzi. Chabanaud (1955b) indicated that the type specimens of $S$. schultzi featured an evenly pigmented reddish-brown ocular side. Though ocular-side pigmentation of these specimens has now largely faded, none of the S. schultzi examined show any traces of incomplete or complete dark-brown or black crossbands that feature so prominently in the ocular-side pigmentation of $S$. thermophilus. 
Meristic features of $S$. thermophilus overlap those of $S$. macrophthalmus, a rarely captured species known only from the holotype and a paratype (in pieces) taken in the Gulf of Aden between 457-549 m (Norman 1939). However, S. thermophilus differs from S. macrophthalmus in its ID pattern (1-2-2-2-2 versus 1-2-2$1-2)$, smaller eye (10.2-16.3\% HL versus $21.1 \%$ in $S$. macrophthalmus) with larger pupil (pupil diameter/eye diameter $55-72 \%$ versus about $54 \%$ in S. macrophthalmus), and color pattern (dark brown ocular-side pigmentation with complete and incomplete crossbands and pigmented blotches versus uniformly pigmented ocular surface without crossbands and blotches in S. macrophthalmus).

Two other Indo-West Pacific species, S. microrhynchus (Weber) and S. trifasciatus (Alcock), have counts for dorsal- and anal-fin rays and abdominal and total vertebrae that overlap those of $S$. thermophilus, and both of these species also have the same ID pattern (1-2-2-2-2) as that of S. thermophilus (Munroe \& Marsh 1997). Symphurus thermophilus differs distinctly from these species, however, in having 14 caudal-fin rays and five hypurals (versus only 12 caudal-fin rays and four hypurals in these others), and S. thermophilus also has a greater number of scales in a longitudinal series compared with those of S. microrhynchus and S. trifasciatus (100-112 versus 77-94 scales and 76-85 scales, respectively).

In some previous studies (Hashimoto et al. 1988; Hashimoto et al. 1995; Ono et al. 1996), S. thermophilus was tentatively identified as $S$. cf orientalis. Symphurus thermophilus is easily distinguished from $S$. orientalis (Bleeker) in having 14 caudal-fin rays (versus 12 in S. orientalis), five versus four hypurals, 47-51 versus 5254 vertebrae, and 100-112 versus 81-87 scales in a longitudinal series (fin-ray, vertebrae and scale data for $S$. orientalis from Ochiai 1963:103; otherwise data from Munroe 1992). In addition to morphological differences, the two species also occur in distinctly different ecological and bathymetric habitats. Symphurus orientalis occurs in non-vent areas on the outer continental shelf in the western Pacific generally at shallower depths (about 50-200 m; Ochiai 1963) than those occupied by S. thermophilus.

\section{Discussion}

Symphurus thermophilus, the only known pleuronectiform species among some 25 species of fishes representing 12 families that have been identified from active hydrothermal vent regions worldwide (Biscoito et al. 2002; Biscoito 2006), occurs in sufficiently high abundances at hydrothermal sites on Kaikata Seamount (2.48 individuals $/ \mathrm{m}^{2}$ ), Kasuga-2 Seamount, Nikko Seamount and depression C at Minami-Ensei Knoll to be considered one of the co-dominant megafaunal species occurring at these habitats (Hashimoto et al. 1995; Ono et al. 1996; Fujikura et al. 1998; Merle et al. 2004; Miyake et al. 2007). In situ observations of this deep-sea tonguefish from submersibles and ROVs (Hashimoto et al. 1988; 1995; Ono et al. 1996; Merle et al. 2004) provide detailed information on the microhabitat, behavior and natural population density (Fujikura et al. 2002) of this species. Detailed microhabitat information, not generally available through traditional means (trawls, dredges) employed to capture deep-sea fishes, provides an invaluable resource for understanding the biology and fine-scale distribution for these species. Visual observations of tonguefishes not only document their occurrences at hydrothermal areas, but they also represent some of the first, direct observations of deepwater tonguefishes in their natural habitat. Most deepwater specimens of Symphurus have been taken in trawls or benthic dredges with the only accompanying ecological data for these captures usually consisting of depth and locality information. Rarely, brief notes on habitat characteristics, such as composition of the substratum (Alcock 1889a; Alcock 1892) or bottom temperatures in the general area where specimens were collected (Alcock 1889b; Alcock 1892), may also have been provided. However, observations on substratum characteristics accompanying trawl or dredge collections are often based on indirect assessments of sedimentary materials, which, depending upon duration of sampling and patchiness of microhabitats, may or may not accurately reflect the actual microhabitat that these specimens were inhabiting prior to their capture. Munroe and McCosker (2001) provide the only other data on microhabitat and relative within-habitat density for a deep- 
water species of Symphurus (S. diabolicus Mahadeva \& Munroe) also using observations made from a submersible.

Many fishes occurring at or near hydrothermal vents are considered vagrant species and most likely 'visitors' to the vent sites (Tunnicliffe et al. 1998). Symphurus thermophilus, in contrast, has been observed only at active hydrothermal vent sites and is considered an obligate, vent-associated megafaunal species (Hashimoto et al. 1995; Ono et al. 1996; Fujikura et al. 1998). This species is unknown from habitats adjacent to active hydrothermal sites or at inactive sites, nor is it known from cold seep environments located in the same general geographic region (Sibuet \& Olu 1998; Fujikura et al. 2002). High densities of S. thermophilus at several active vent sites, including areas of warm shimmering water, further support the idea that this species is a regular component of the fauna inhabiting vents located at appropriate depths (see below) over a broad geographic area in the western Pacific. Symphurus thermophilus may in fact prefer the warmer water temperatures found at active vent sites compared with those found in non-vent sites at comparable depths. Miyake et al. (2007), for example, successfully maintained S. thermophilus in an artificial hydrothermal vent tank at $12^{\circ} \mathrm{C}$ where the species not only survived, but actively fed and spawned. Eggs and larvae developed over a temperature range from $12^{\circ} \mathrm{C}$ to $26^{\circ} \mathrm{C}$.

Where found, $S$. thermophilus occurs on fine and coarse sandy sediments, as well as gravel, cobble and rocky bottoms (Hashimoto et al. 1995; Merle et al. 2004), including some sites with extensive sulphur deposits (Ono et al. 1996). In sedimentary habitats at Minami-Ensei Knoll, the concentration of $\mathrm{H}_{2} \mathrm{~S}$, which can be toxic to non-vent organisms in high concentrations, was lower than that measured in the adjacent rocky field (Hashimoto et al. 1995). Reduced levels of $\mathrm{H}_{2} \mathrm{~S}$ in the sedimentary field at Minami-Ensei Knoll (and elsewhere) may explain the presence of large numbers of tonguefishes in active hydrothermal areas where they can exploit the rich organic production of the vent system (Hashimoto et al. 1995). A variety of non-vent organisms are usually concentrated in higher abundance in the peripheral zones of these vent sites as well.

Symphurus thermophilus is present at some, but not all, hydrothermal vent sites studied. No tonguefishes were found at the Kasuga-3 site where active hydrothermal vents were not observed and where water depths exceeded $1000 \mathrm{~m}$ (Fujikura et al. 1998), nor were they present at depressions A or B of the Minami-Ensei Knoll area (Hashimoto et al. 1995), or at several sites surveyed by Merle et al. (2004). In addition to food resource availability and abundance, physico-chemical factors undoubtedly influence distributions of tonguefishes at vent sites. Such factors include substratum type and distribution, degree of hydrothermal activity and warm water percolation through sediments, levels of $\mathrm{H}_{2} \mathrm{~S}$ present at the benthic-boundary interface (high levels of $\mathrm{H}_{2} \mathrm{~S}$ are toxic to both flatfishes and their prey), and depths where vent sites are located.

Symphurus thermophilus is found over a more restricted range of depths (239-733 m) than are hydrothermal vent sites located in the same geographic area where this species has been recorded. The more restricted bathymetric distribution of $S$. thermophilus compared to the depth range where suitable habitat may be available is not unusual among symphurine tonguefishes. Many deep-sea species of Symphurus have depth ranges usually encompassing only a few hundred meters (depth information for species of Symphurus summarized in Munroe 1992; Munroe 1998; Krabbenhoft \& Munroe 2003). Most tonguefishes occur shallower than $1000 \mathrm{~m}$, and the deepest capture recorded for any member of the genus ( $S$. australis McCulloch) is about $1500 \mathrm{~m}$. The absence of $S$. thermophilus and other species of Symphurus at hydrothermal sites (or other habitats) located below about $1000 \mathrm{~m}$ may reflect depth limitations for this group of fishes.

Symphurus thermophilus does not display any features different from those observed in other deepwater species of Symphurus that would indicate morphological specializations uniquely adapted for life at the hydrothermal vents. Fish species at hydrothermal vents do not feature anatomical specializations for this environment (Geistdoerfer 1996; Biscoito 2006). Osteological evidence available from radiographs of specimens included in this study and other specimens (Munroe unpubl. data) indicates that skeletal features of S. thermophilus may be negatively impacted by environmental conditions (temperature fluctuations, heavy metal exposure, $\mathrm{pH}$ fluctuations) in habitats where this species lives. Several specimens have fin rays only partially 
developed (Table 1). For these specimens, no obvious external damage was evident to indicate that they had been recently injured by predators, or had been damaged during capture. Several specimens have missing dorsal- and/or anal-fin rays. In these fishes, supporting pterygiophores for the missing rays are present, but the corresponding fin rays did not develop. One fish is missing about 10 dorsal-fin rays, the largest number of missing fin rays noted among specimens examined. Four of 16 specimens have a fully developed caudal fin; three others have only 13 fully developed caudal-fin rays with either another broken fin ray (1 specimen), or with the $14^{\text {th }}$ fin ray visible basally only as a partially developed fin ray ( 2 specimens). The specimen in USNM 383313 has the most dramatic anomaly in which its caudal fin is severely misshapen and comprises only 8 caudal-fin rays (as many as 6 fin rays missing). It is unknown if this condition results from developmental abnormality or was caused by previous injury from a predator. Large crabs, such as Austinograea williamsi Hessler and Martin and A. yunohana Takeda, Hashimoto and Ohta, are common and abundant at several vent sites where tonguefishes are found. Although predators and predation levels on $S$. thermophilus are unknown, an unsuccessful attack on a tonguefish by a crab (perhaps a member of Austinograea) was observed during one dive at the Kasuga-2 Seamount (Merle et al. 2004:249) and bythograeid crabs have also been observed attempting attacks on tonguefishes at both the Kaikata and Nikko seamounts (Hashimoto pers. obs.).

Several anomalies were also observed in bones of the hypural complex of the $S$. thermophilus. Thirteen of 15 specimens radiographed have five hypurals, which is the common count observed among species of Symphurus with 14 caudal-fin rays (Munroe 1992). However, one specimen has only four hypurals with the dorsalmost hypural twice as wide as the others, which may indicate fusion of hypurals four and five. Another specimen has six hypurals, a count not observed in any of 4000+ specimens of Symphurus species previously examined (Munroe 1992; Munroe 1998; Munroe unpubl. data).

Though no special morphological adaptations are apparent, S. thermophilus and other vent-dwelling fishes survive in demanding environments situated between the super-heated discharge of thermal vents and the surrounding cold waters of the deep sea. These habitats are characterized by fluctuating water temperatures, varying $\mathrm{pH}$ and dissolved oxygen levels, high $\mathrm{H}_{2} \mathrm{~S}$ levels, high levels of heavy metals and temporal episodes of tectonic activity. Adaptations for survival in these harsh and unpredictable conditions of the hydrothermal vents likely are manifested in biochemical or behavioral adaptations (Geistdoerfer 1996; Weber et al. 2003), aspects of the biology of these species much in need of further study.

\section{Acknowledgements}

T. Munroe thanks the Japan Society for the Promotion of Science Fellowship Program and the Te Papa Biosystematics of New Zealand's Exclusive Economic Zone Fishes subcontract within NIWA's Marine Biodiversity and Biosecurity OBI programme (contract C01X0502, C.D. Roberts, Program Leader) for funding support that provided opportunities to study fish collections located in Japan and New Zealand, respectively. T. Krabbenhoft and B. Marsh assisted with data capture and comparative information for several Indo-Pacific tonguefishes. L. Willis, D. Smith, J. Clayton, J. Finan, A. Stewart, C. Roberts, C. Struthers, M. Clark, R. Embley, K. Shibukawa and K. Matsuura provided assistance with specimens, field data, accessioning and/or catalogue information. S. Juniper graciously provided the specimen and station data from his work at the Kasuga2 Barnacle Boulders site, Marianas Islands. M. Clark provided specimens and station data for fishes collected during the 2005 NOAA Ring of Fire Expedition, under the NIWA Seamounts Programme (FRST contract No. CO1X0508). L. Willis and C. Struthers assisted with radiographs. We thank the curators of the many collections from which we examined fishes for providing us access to specimens in their care. Operation teams of the submersibles Shinkai 2000 and Pisces V and captains and crews of the R/V Natsushima and R/V Tangaroa are acknowledged for their support during field sampling. D. Cole assisted with preparation of the map. We appreciate the efforts of librarians at NOAA, Smithsonian Institution and Virginia Institute of Marine Science 
for assistance in locating critical references. S. Raredon provided photographs of the holotype. Earlier drafts of the manuscript were reviewed by M. Nizinski and B. Collette.

\section{References}

Alcock, A. (1889a) XVI. Natural history notes from H.M. Indian Marine Survey Steamer Investigator, Commander Alfred Carpenter, R.N., D.S.O., commanding. No. 10. List of the Pleuronectidae obtained in the Bay of Bengal in 1888 and 1889, with descriptions of new and rare species. Journal of the Asiatic Society of Bengal, 58(Pt. II, No. 3), 279-295.

Alcock, A. (1889b) XVI. Natural history notes from H.M. Indian Marine Survey Steamer 'Investigator,' Commander Alfred Carpenter, R.N., D.S.O., commanding. No. 13. On the bathybial fishes of the Bay of Bengal and neighboring waters, obtained during the seasons 1885-1889. The Annals and Magazine of Natural History (6 ${ }^{\text {th }}$ Series), 4, 376399.

Alcock, A. (1892) Natural history notes from H.M. Indian Marine Survey Steamer Investigator, Lieut. G.S. Gunn, R.N., commanding. Series II., No. 5. On the bathybial fishes collected during the season of 1891-1892. The Annals and Magazine of Natural History ( $6^{\text {th }}$ Series), 10, 345-358.

Alcock, A. (1894) Natural history notes from H.M. Indian Marine Survey Steamer Investigator, Commander C.F. Oldham, R.N., commanding. Series II., No. 11. An account of a recent collection of bathybial fishes from the Bay of Bengal and from the Laccadive Sea. Journal of the Asiatic Society of Bengal, 63(Part II, No. 2), 115-137.

Alcock, A. (1899) A descriptive catalogue of the Indian deep-sea fishes in the Indian Museum, collected by the R.I.M.S. Investigator. Government Printing, Calcutta, $220 \mathrm{pp}$.

Biscoito, M., Segonzac, M., Almeida, A.J., Desbruyères, D., Geistdoerfer, P., Turnipseed, M. \& Van Dover, C. (2002) Fishes from the hydrothermal vents and cold seeps-An update. Cahiers de Biologie Marine, 43(3-4), 359-362.

Biscoito, M. (2006) Chordata, Chondrichthyes \& Osteichthyes. In: Desbruyères, D., Segonzac, M. \& Bright, M. (Eds.), Handbook of deep-sea hydrothermal vent fauna ( $2^{\text {nd }}$ Ed.). Denisia, 18, pp. 489-490.

Chabanaud, P. (1954) Notules ichthyologiques (suite). Notule 46. Description d'un nouveau Symphurus de la côte sud de l'Arabie. Bulletin du Muséum National D'Histoire Naturelle Paris ( $2^{\text {nd }}$ Séries), 26, 464-467.

Chabanaud, P. (1955a) Revision des Symphurus du Siboga. Beaufortia, 5(46), 43-45.

Chabanaud, P. (1955b) Flatfishes of the genus Symphurus from the U.S.S. "Albatross" Expedition to the Philippines, 1907-1910. Journal of the Washington Academy of Sciences, 45(1), 30-32.

Chabanaud, P. (1955c) Sur cinq espèces du genre Symphurus, don't trois sont inèdites. Bulletin du Muséum National D'Histoire Naturelle Paris (2 ${ }^{\text {nd }}$ Séries), 27, 368-370.

Chabanaud, P. (1956) Les Symphurus marbrés du complexe Indo-Pacifique tropical. Archives du Muséum National D'Histoire Naturelle Paris (7 $7^{\text {th }}$ Séries), 4, 79-100.

Chanet, B. \& Wagemans, F. (1997) Presence of double spines on the second preural centrum of the turbot (Scophthalmus maximus L., Pleuronectiformes: Scophthalmidae). Belgian Journal of Zoology, 127(2), 115-122.

Chapleau, F. (1988) Comparative osteology and intergeneric relationships of the tongue soles (Pisces; Pleuronectiformes; Cynoglossidae). Canadian Journal of Zoology, 66, 1214-1232.

Fujikura, K., Hashimoto, J. \& Okutani, T. (2002) Estimated population densities of megafauna in two chemosynthesisbased communities: a cold seep in Sagami Bay and a hydrothermal vent in the Okinawa Trough. Benthos Research, $57(1), 21-30$.

Fujikura, K., Tsuchida, S., Ueno, H., Ishibashi, J., Gaze, W. \& Maki, Y. (1998) Investigation of the deep-sea chemosynthetic ecosystem and submarine volcano at the Kasuga 2 and 3 Seamounts in the Northern Mariana Trough, western Pacific. JAMSTEC Journal of Deep Sea Research, 14, 127-138 (In Japanese with English abstract and legends).

Geistdoerfer, P. (1996) L'ichthyofaune des écosystèmes associès à l'hydrothermalisme océanique: état des connaissances et résultats nouveaux. Oceanolgica Acta, 19(5), 539-548.

Hashimoto, J., Hotta, H. \& Deep Sea Survey Group (1988) The biological communities found at the vicinity of the central cone of the Kaikata Caldera, west of Chichijima Island, Ogasawara (Bonin) Islands. Abstract Papers, $5^{\text {th }}$ symposium of Shinkai 2000 study. JAMSTEC Journal of Deep Sea Research, 5, 87-88 (in Japanese).

Hashimoto, J., Ohta, S., Fujikura, K. \& Miura, T. (1995) Microdistribution pattern and biogeography of the hydrothermal vent communities of the Minami-Ensei Knoll in the Mid-Okinawa Trough, Western Pacific. Deep-Sea Research Part I, 42(4), 577-598.

Hensley, D.A. \& Ahlstrom, E.H. (1984) Pleuronectiforms: Relationships. In: Moser, H.G., Richards, W.J., Kendall, A.W., Fahay, M.P., Richardson, S.L. \& Cohen, D.M. (Eds.), Ontogeny and Systematics of Fishes Special Publications of the American Society of Ichthyologists and Herpetologists, 1, pp. 670-687.

Krabbenhoft, T.J. \& Munroe, T.A. (2003) Symphurus bathyspilus: a new cynoglossid flatfish (Pleuronectiformes: Cyno- 
glossidae) from deepwaters of the Indo-West Pacific. Copeia, 2003(4), 810-817.

Merle, S., Ristau, S., Embley, R.W. \& Chadwick, W. (Compilers) (2004) Cruise report: Submarine Ring of Fire 2004Mariana Arc Submarine Volcanoes, RV Thomas G. Thompson Cruise TN1167, ROPOS dives R782-R795, March 27-April 17, Chief Scientist R.W. Embley. Available from http://oceanexplorer.noaa.gov/explorations/04fire/logs/ summary/summary.html (Accessed 3 June 2008)

Miyake, H., Mitsugu, K., Tsuchida, S., Okuyama, Y. \& Nakamura, K. (2007) Ecological aspects of hydrothermal vent animals in captivity at atmospheric pressure. Marine Ecology, 28, 1-7.

Munroe, T.A. (1992) Interdigitation pattern of dorsal-fin pterygiophores and neural spines, an important diagnostic character for symphurine tonguefishes (Symphurus: Cynoglossidae: Pleuronectiformes). Bulletin of Marine Science, 50(3), 357-403.

Munroe, T.A. (1998) Systematics and ecology of tonguefishes of the genus Symphurus (Cynoglossidae: Pleuronectiformes) from the western Atlantic Ocean. Fishery Bulletin, 96(1), 1-182.

Munroe, T.A. (2006) New western Indian Ocean tonguefish (Pleuronectiformes: Cynoglossidae, Symphurus). Copeia, 2006(2), 230-234.

Munroe, T.A. \& Mahadeva, M.N. (1989) Symphurus callopterus (Cynoglossidae, Pleuronectiformes), a new deepwater tonguefish from the eastern Pacific. Proceedings of the Biological Society of Washington, 102(2), 458-467.

Munroe, T.A. \& Marsh, B.N. (1997) Taxonomic status of three nominal species of Indo-Pacific symphurine tonguefishes (Symphurus: Cynoglossidae: Pleuronectiformes). Ichthyological Research, 44(2), 189-200.

Munroe, T.A. \& McCosker, J.E. (2001) Redescription of Symphurus diabolicus Mahadeva and Munroe, a poorly-known, deep-sea tonguefish (Cynoglossidae: Pleuronectiformes) from the Galápagos Archipelago. Revista de Biologia Tropical, 49(Suppl. 1), 187-198.

Norman, J.R. (1939) Fishes. The John Murray expedition. 1933-1934. Scientific Reports, John Murray Expedition, 7, 1116.

Ochiai, A. (1963) Fauna Japonica. Soleina (Pisces). Biogeographical Society of Japan, Tokyo, 114 pp.

Ono, T., Fujikura, K., Hashimoto, J., Fujiwara, Y. \& Segawa, S. (1996) The hydrothermal vent community at the Kaikata Seamount near Ogasawara (Bonin) Islands, South Japan. JAMSTEC Journal of Deep Sea Research, 12, $221-230$ (In Japanese with English abstract and legends).

Rosen, D.E. (1973) Interrelationships of higher euteleostean fishes. In: Greenwood, P.H., Lies, R.S. \& Patterson, C. (Eds.) Interrelationships of fishes. Zoological Journal of the Linnean Society, 53(Suppl. 1), pp. 397-536.

Sibuet, M., \& Olu, K. (1998) Biogeography, biodiversity and fluid dependence of deep-sea cold-seep communities at active and passive margins. Deep-Sea Research Part II, 45, 517-567.

Tunnicliffe, V., McArthur, A.G. \& McHugh, D. (1998) A biogeographical perspective of the deep-sea hydrothermal vent fauna. Advances in Marine Biology, 34, 353-442.

Weber, R.E., Hourdez, S., Knowles, K. \& Lallier, F. (2003) Hemoglobin function in deep-sea and hydrothermal-vent endemic fish: Simenchelis [sic] parasitica (Anguillidae) and Thermaces [sic] cerberus (Zoarcidae). Journal of Experimental Biology, 206, 2693-2702. 